\title{
New synthesis for nano-silver formulated as a bio-safe composite structure to employ against hepatotoxicity in
}

\section{rats}

\author{
Eman I. Abdel-Gawad ${ }^{1}$, Emad M. El-Sherbiny ${ }^{1}$ and Sameh A. Awwad ${ }^{2}$ \\ ${ }^{1}$ Radioisotopes Department, Atomic Energy Authority, Egypt \\ ${ }^{2}$ Department of Chemical Engineering, Higher Institute of Engineering \& Technology, New Damietta, Egypt
}

\begin{abstract}
Objective: This study was planned to investigate the possible therapeutic effects of newly synthesis method of nano-silver ( $\mathrm{nAg}$ ) on hepatotoxicity induced by lead nitrate exposure in albino rats.

Design and Methods: Rats were designed into three groups. (1) normal control. (2) rats were injected with lead nitrate. (3) rats were injected with lead nitrate followed by nano-silver/hydroxyl apatite ( $\mathrm{nAg} / \mathrm{HAp}$ ). The degree of DNA fragmentation was analyzed, in addition to immune status, by measuring the levels of interferon- $\gamma(\mathrm{IFN}-\gamma)$, tumor necrosis factor- $\alpha$ (TNF- $\alpha$ ), and interleukin-2 (IL-2). The activities of superoxide dismutase (SOD) and glutathione peroxidase (GPx) and malondialdehyde (MDA) content as well as liver enzymes were measured. The levels of hepatic heat shock protein-70 (HSP-70), caspase-3, and metalloproteinase-9 were also measured as markers for inflammation and apoptosis. Histopathological examination of liver tissue was performed. Results: The results revealed the potent efficacy of $\mathrm{nAg} / \mathrm{HAp}$ composite in repairing the fragmented DNA and ameliorating most of the investigated parameters by significant elevation in the levels of hepatic alanine aminotransferase (ALT), SOD, and (GPx) activities. Conversely, there was a significant decrease in hepatic gamma-glutamyl transpeptidase ( $\gamma$-GT), MDA, IL-2, IFN- $\gamma$, TNF- $\alpha$, matrix MMP-9, HSP-70, and caspase-3 levels upon treatment. Histopathological findings were correlated with biochemical results and confirmed the difference between the lead-intoxicated and nAg-treated groups and achieved by disappearance most of the pathological phenomenon in treated rats.
\end{abstract}

Conclusion: The results illustrated newly synthesis and characterization for $\mathrm{nAg}$ preparation carried by $\mathrm{nHAp}$, which provides a biosafe composite with unique chemical and biological properties possess anti-hepatotoxicity effect.

\section{Introduction}

Silver nanoparticles exhibit particularly unique physical, chemical, optical, and biological properties that different from other biomedical nanomaterials and, thus, can serve as therapeutic platforms in many biomedical applications, including antiviral agents, photosensitizers and/or radiosensitizers and anticancer therapeutic agents [1-4].

There is ongoing debate about the beneficial and harmful effects of nAg. Such conflicting opinions owing to the different synthesis methods of silver nanoparticles, their various sizes, shape, surface charge in addition to route, duration and dosage of administration [5-9]. Although numerous studies reported that the toxicity of $\mathrm{nAg}$ is proportional mainly to the released Ag ions [10], they faced difficulties to draw a definite consensus on their cytotoxicity. Some researchers demonstrated that $\mathrm{nAg}$ is thermodynamically favor and their toxicity was attributed to interaction of released $\mathrm{Ag}$ ions with and damaging cell membranes, thiol protein groups and DNA $[11,12]$. While others reported that $\mathrm{nAg}$ has beneficial effects in low doses for the protection of oxidative liver injury [13] and it is non-toxic to the immune, cardiovascular, nervous or reproductive systems $[2,14,15]$. Thus, it was necessary to find a proper method with chemical modification of the $\mathrm{nAg}$ surface with a reduced number of inconveniences related to the physio-chemical properties, in terms of stability, biocompatibility and shape to reduce the potential risks of $\mathrm{nAg}$ on human cells. The toxicity of silver in medical uses could be controlled by trapping silver ions in biosafe composite materials.

Occupational and environmental exposures to lead is remain a serious problem in many developing and industrializing countries because it has many undesired effects, including neurological behaviour, immunological, renal, hepatic, and haematological dysfunctions [16]. The maximum level of $\mathrm{Pb}$ in the liver reached within the first hour after administration which in turn, increases the susceptibility of cells to oxidative attack by altering the fatty acid composition and membrane permeability resulting in escaping of enzymes from cells into blood [17]. Extensive experimental evidence clearly points to potential hepatotoxicity of $\mathrm{Pb}$ which is ranging from simple biochemical and structural alterations to molecular characterization of hepatic hyperplasia. The perturbations mediating events of lead-hepatotoxicity including various metabolic pathways, iron transport, induction of cytokines mediators and pathologic changes [18].

${ }^{\star}$ Correspondence to: Sameh Awwad, Department of Chemical Engineering, Higher Institute of Engineering \& Technology, New Damietta, Egypt, E-mail: sameh.awwad@gmail.com

Keywords: nano silver, anti-hepatotoxicity, lead nitrate, albino rats

Received: May 05, 2021; Accepted: May 13, 2021; Published: May 25, 2021 
This study conducted to develop the formulation structure of $\mathrm{Ag}$ nanocomposite. Nano-Ag constructed chelated by nano-hydroxyl apatite (nHAp) to control its toxicity by trapping Ag+ ions in cellular medium. In addition, performance of intravenous injection of the prepared $\mathrm{nAg} / \mathrm{HAp}$ in relieve the hepatic biochemical and histological symptoms associated with lead nitrate toxicity performed.

\section{Material and methods}

\section{Chemicals}

The chemicals used for $\mathrm{nAg}$ preparation were, polyvinylpyrrolidone (PVP), sodium hydroxide $(\mathrm{NaOH})$, ammonium hydroxide $\left(\mathrm{NH}_{4} \mathrm{OH}\right.$, Mwt. 35.5g/mole, May \& Baker, England). Calcium nitrate tetrahydrate $\left(\mathrm{Ca}\left(\mathrm{NO}_{3}\right)_{2} \cdot 4 \mathrm{H}_{2} \mathrm{O}\right.$, Mwt. $236.15 \mathrm{~g} / \mathrm{mole}$, Merk, Germany), di ammonium hydrogen ortho phosphate (anhydrous $\left(\mathrm{NH}_{4}\right)_{2} \mathrm{HPO}_{4}, 132.06 \mathrm{~g} / \mathrm{mole}$, S.D. Fine Chem. Ltd. Mumbai), poly vinyl alcohol (PVAL) (Mwt. $\approx 160000 \mathrm{~g} / \mathrm{mole})$, Silver nitrate, $\left(\mathrm{AgNO}_{3}\right.$, Mwt.169.88g/mole, Johnson Matthey). All these chemicals were used without further purification and all solutions were prepared with deionized water. Lead nitrate powder was dissolved in $0.9 \%$ saline.

\section{Fabrication of nAg/HAp}

The synthesis of Ag/HAp nanocomposite performed according partially, to Díaz, et al. [19] technique with some modification. A polymeric matrix route used to synthesize $\mathrm{nAg}$ by dissolved poly vinyl alcohol in deionized water at $80^{\circ} \mathrm{C}$, then calcium nitrate as well as ammonium phosphate added by their natural ratio [20]. Silver nitrate dissolved separately in deionized water and added to the mixture under $\mathrm{pH}$ control. The adding ratios with $1 / 5$ times to $\mathrm{LD}_{50}$ of silver nitrate. The formed composite gel dried at $80^{\circ} \mathrm{C}$ for 24 hours and analyzed using, Scanning electron microscope (SEM), with EDAX unit and Transmission Electron Microscopy (TEM). The produced gel was dried and characterized to confirm the formation of $\mathrm{nAg} / \mathrm{Hap}$ nanocomposite.

\section{Animals}

Twenty-one male albino rats Rattus rattus ( $180 \pm 20$ g body weight) were housed in standard laboratory condition with alternating dark and light cycle of $12 \mathrm{~h}$ each, temperature of $25^{\circ} \mathrm{C}$ and suitable humidity. Animals were maintained without limitation on standard pellets food and water ad libitum for 2 weeks, to acclimatize them to laboratory environment before the experimentation. The study was conducted in accordance with the guidelines set by the CIOHS \& ICLAS International Guiding Principles for Biomedical Research involving animals (2012) which accordance with the Guide for the Care and Use of Laboratory Animals (Eighth Edition, 2011, published by The National Academies Press, 2101 Constitution Ave. NW, Washington, DC 20055, USA). This guide was approved by the Ethical Committee at National Center for Radiation Research, Egyptian Atomic Energy Authority, Cairo, Egypt (NCRR- EAEA).

\section{Animal's treatment}

The animals were received intraperitoneal injection of lead nitrate solution with a dose of $7.7 \mathrm{mg} / \mathrm{kg}$ b.wt. three times/week for two successive weeks which is collectively equivalent to $1 / 2$ LD50 (ASTDR, 1999). Conjoint treatments of synthesized $\mathrm{nAg}$ were given after $24 \mathrm{~h}$ of toxicant administration weekly as four intravenous injections with a dose of $50 \mathrm{mg} / \mathrm{kg}$ b.wt. Rats were randomly divided into three groups ( 8 rats in each group) as follows:

Group 1: rats were served as controls, just received water and food.
Group2: rats were received lead nitrate solution.

Group3: rats were received lead nitrate as group 2 and treated with nAg/HAp.

All animals were euthanized after $24 \mathrm{~h}$ of last treatment, their abdomen was dissected, and livers were separated carefully. Livers were immediately washed with ice-cold saline, then dried with filter papers. Each rat liver was divided into three parts, one part fixed in $10 \%$ formalin solution for histopathological examination, second and third parts were fixed in saline and stored at $-800 \mathrm{C}$ for analysis of DNA fragmentation and biochemical assays.

\section{Apoptotic DNA fragmentation studies}

DNA damage of treated and untreated rats was assessed by the detection of DNA fragmentation through agarose gel electrophoresis as previously described by Bortner, et al. [21]. A small piece of liver $(0.2 \mathrm{~g})$ was put in a homogenizer with $0.8 \mathrm{~mL}$ of ice-cold PBS and homogenized for $1 \mathrm{~min}$. To each $200 \mu \mathrm{L}, 700 \mu \mathrm{L}$ lysis buffer [50 mmol $\mathbb{} \mathrm{L}-1$ Tris +1 mmol $₫ \mathrm{~L}-1$ EDTA $+150 \mathrm{mmol} \mathbb{} \mathrm{L}-1 \mathrm{NaCl}+0.2 \%$ Triton X-100] and $50 \_\mathrm{g} \bigotimes \mathrm{mL}-1$ of proteinase $\mathrm{K}$ were added and incubated at $50{ }^{\circ} \mathrm{C}$ for 2 h. To $500 \mu \mathrm{L}, 100 \mu \mathrm{L}$ of ice-cold 5 mol $\mathbb{\mathrm { L }}-1 \mathrm{NaCl}$ were added and vigorously vortexed, then $700 \mu \mathrm{L}$ of ice-cold isopropanol were added and again vigorously vortexed. Precipitation could proceed overnight at $-20^{\circ} \mathrm{C}$. After precipitation, DNA was recovered by pelleting for $10 \mathrm{~min}$ at $20000 \mathrm{~g}$ at $4{ }^{\circ} \mathrm{C}$. The supernatants were discarded, and the pellets were rinsed by adding $700 \mu \mathrm{L}$ of ice-cold $70 \%$ ethanol and centrifuging at 20 $000 \mathrm{~g}$ for $10 \mathrm{~min}$ at $4{ }^{\circ} \mathrm{C}$. The supernatants were again discarded, and the ethanol was removed, and the DNA pellet was dried and dissolved in $100 \mu \mathrm{L}$ of Tris-EDTA buffer. The extent of DNA fragmentation was assessed by agarose gel electrophoresis containing $0.5 \mathrm{mg} \bigotimes \mathrm{mL}-1$ ethidium bromide at $5 \mathrm{~V} \otimes \mathrm{cm}-1$ for $1 \mathrm{~h}$. DNA was visualized by placing the gel on a UV transilluminator and the amount of DNA fragmentation in individual rat livers was quantified using Image Analyzer software (version 1.36.1).

Infrared Analysis (IR) of the products was carried out with Mattson Infinity Series FTIR made in USA. High resolution transmission electron microscope (TEM) JEOL2100 was used in microscope characterization. X-Ray Diffraction (XRD) analysis of the dried and calcined Ag/HAp nano composite powders was detected using Bruker AXS-D8 Advance XRD System (Germany made). Scanning Electron Microscopy (SEM) scan of samples was performed on Philips XL30 scanning electron microscope made in Holland. EDAX analysis using EDAX (Ametek).

\section{Preparation of liver homogenate}

Liver homogenate (20\%) was prepared by homogenizing $2 \mathrm{~g}$ of liver in either lysis buffer ( $\mathrm{pH}$ 7.4) or phosphate-buffered saline (PBS; $\mathrm{pH}$ 7.4 ), and then the whole homogenate was centrifuged at $20000 \mathrm{~g}$ for $20 \mathrm{~min}$ at $4{ }^{\circ} \mathrm{C}$ in a cooling centrifuge to obtain the cytosolic fraction with the post-mitochondrial fraction for each sample, and the whole homogenate and cytosolic fraction were then used.

\section{Hepatic tissues biochemical analyses}

Tumor necrosis factor- $\alpha$ (TNF- $\alpha$ ) was measured by radioimmunoassay technique according to the method of Teppo and Maury [22] Interferon- $\gamma$ (IF- $\gamma$ ) by the method of Staehelin, et al. [23]. IL-2, HSP-70, MMP-9, and caspase-3 levels were assessed using sandwich ELISA kits (DuoSet IC, Human/Mouse/Rat Total HSP70, Catalog no. DYC 1663-2, USA, USCN Life Science, Rat MMP-9, 
Catalog no. E90553, China, and USCN Life Science, Rat caspase-3, Catalog no. E90626, China) according to the manufacture instructions.

Assessment of oxidant/antioxidant status in hepatic tissues was performed by measuring the activities of the most important freeradical scavengers of the antioxidant defense system, SOD and GPx as well as the product of lipid peroxidation, MDA content according to the colorimetric method of Janknegt, et al. [24], Paglia and Valentine [25] and Erdelmeier, et al. [26], respectively. The extent of hepatic alteration was ensured by liver function test biomarkers, viz. ALT, and $\gamma$-GT according to the methods of Reitman and Frankel [27] and Young [28] respectively.

\section{Histological studies}

Autopsy samples were taken from the liver of rats in different groups and fixed in $10 \%$ formalin for twenty-four hours. Washing was done in tap water then serial dilutions of alcohol (methyl, ethyl and absolute ethyl) were used for dehydration. Specimens were cleared in xylene and embedded in paraffin at $56^{\circ} \mathrm{C}$ in hot air oven for 24 hours. Paraffin bees wax tissue blocks were prepared for sectioning at 4 microns by slidge microtome. The obtained tissue sections were collected on glass slides, deparaffinized and stained by hematoxylin and eosin stains (Banchroft, et al.) for histopathological examination through the electric light microscope.

\section{Statistical analysis}

The values presented are the mean \pm SE. Data were analyzed using a one-way analysis of variance (ANOVA). The level of significance between mean values was set at $\mathrm{p} \leq 0.05$. All statistical analyses were performed using SPSS software (version 20.0).

\section{Results}

\section{Characterization of $\mathbf{n A g}$}

The formed nanocomposite contains nAg chlated by nHAp was analyzed using, Scanning electron microscope (SEM), Transmission Electron Microscopy (TEM) and energy-dispersive X-ray Analysis spectroscopy (EDAX). SEM analysis was clearly showed that $\mathrm{nAg}$ synthesized in the nano range $(75-80 \mathrm{~nm})$ dispersed successfully in the carrier nHAp (Figure 1). While the EDAX analysis detected the presence of $\mathrm{nAg}$ after filtration and drying, with its percentage as the analysis of filtered solution, without appearance of silver or calcium ions (Figure 2). On the other hand, TEM showed the distribution of agglomerated silver on the carrier as represented in Figure 3. The characteristic XRD pattern showed the formation of the carrier nHAp with molar ratio 1.67 and the presence of nAg didn't change the crystals structure of nHAp.

\section{DNA fragmentation}

DNA was highly fragmented in liver of lead-intoxicated rats as the intact DNA was reduced to $52.39 \%$ and $54.62 \%$ respectively in two liver samples, compared to $100 \%$ intact DNA in the normal control group. However, treatment with nano-Ag following lead intoxication repaired the fragmented DNA and raised the intact DNA proportion to $69.16 \%$ and $68.89 \%$ respectively in two liver samples (Figure 4 ).

\section{Biochemical results}

In assessment of molecular markers, intoxication of rats with lead nitrate resulted in a sharp increase in MMP-9 concentration and moderate increase in the concentrations of both HSP-70 and caspase- 3 compared to the normal controls. On the other hand, treatment with

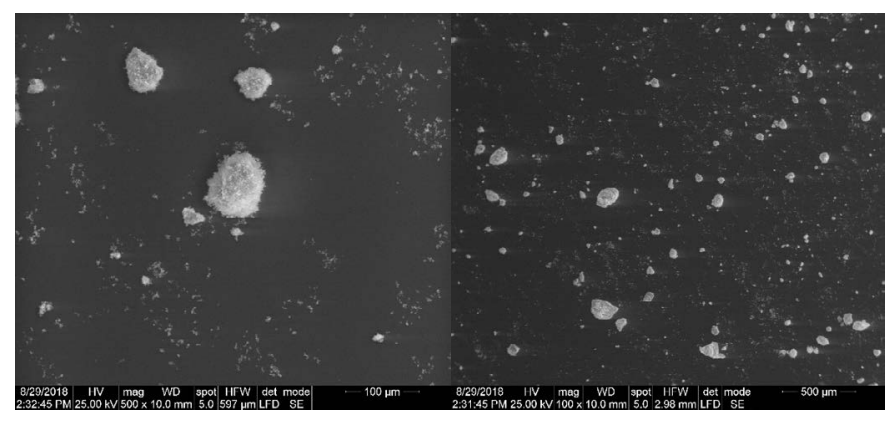

Figure 1. SEM of sample prepared after drying

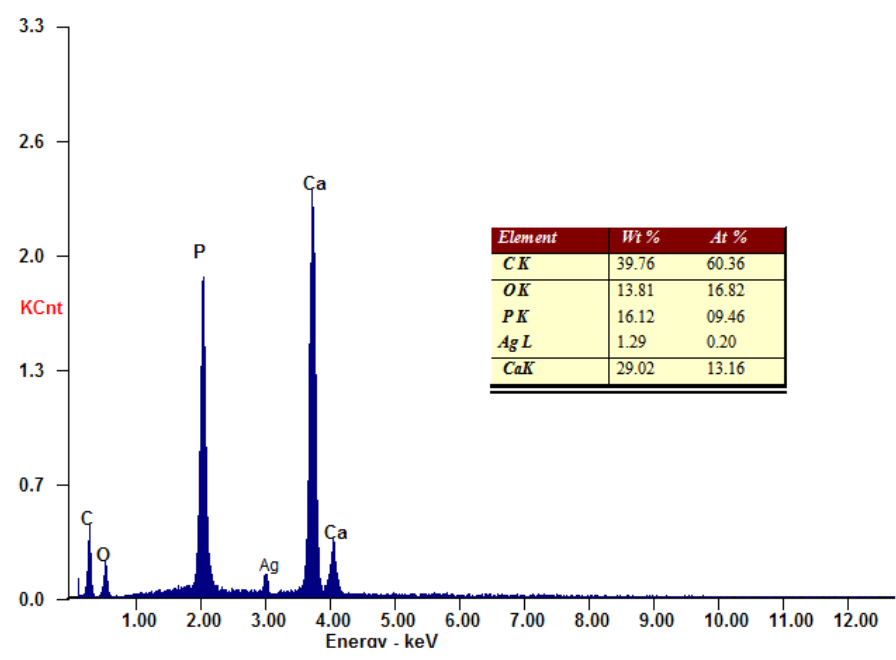

Figure 2. EDAX analysis of nAg carried by nHAp and dried at $80^{\circ} \mathrm{C}$ for $24 \mathrm{~h}$

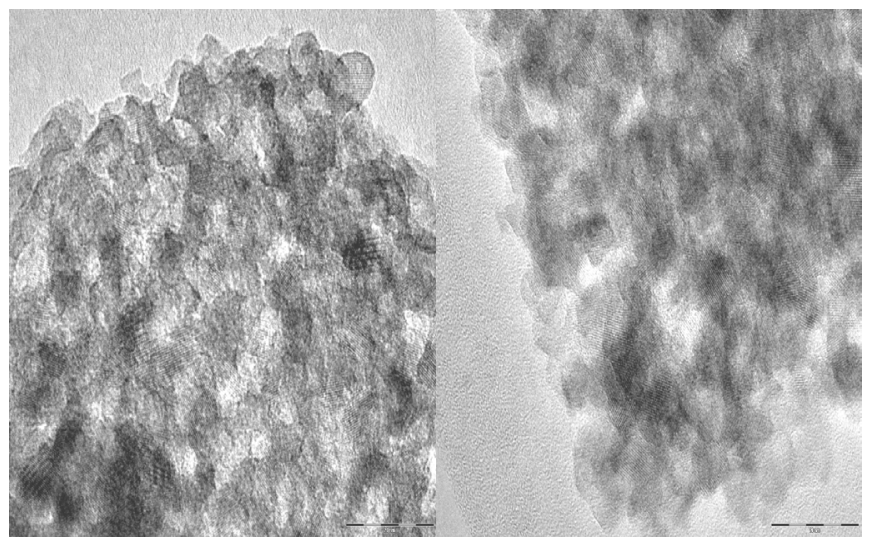

Figure 3. (A) low concentration of $\mathrm{nAg}$ (B) High concentration of $\mathrm{nAg}$. TEM of the prepared nAg

nAg following lead intoxication produced significant reductions in the levels of HSP-70, MMP-9 and caspase-3 compared to the control rats. Nevertheless, the liver contents of HSP-70, MMP-9 and caspase- 3 were still significantly higher than the normal levels as shown in Table 1.

Intoxication of rats with lead nitrate resulted in significant increase in liver contents of IL-2, TNF- $\alpha$ and IFN- $\gamma$ compared to the normal control group. However, treatment with $\mathrm{nAg}$ following lead intoxication resulted in significant reductions in the levels of IL-2, TNF- $\alpha$ and IFN- $\gamma$ compared to lead-intoxicated rats. Meanwhile, the levels of IL-2, TNF- $\alpha$ and IFN- $\gamma$ were still significantly higher than the normal levels upon treatment as illustrated in Table 2. 


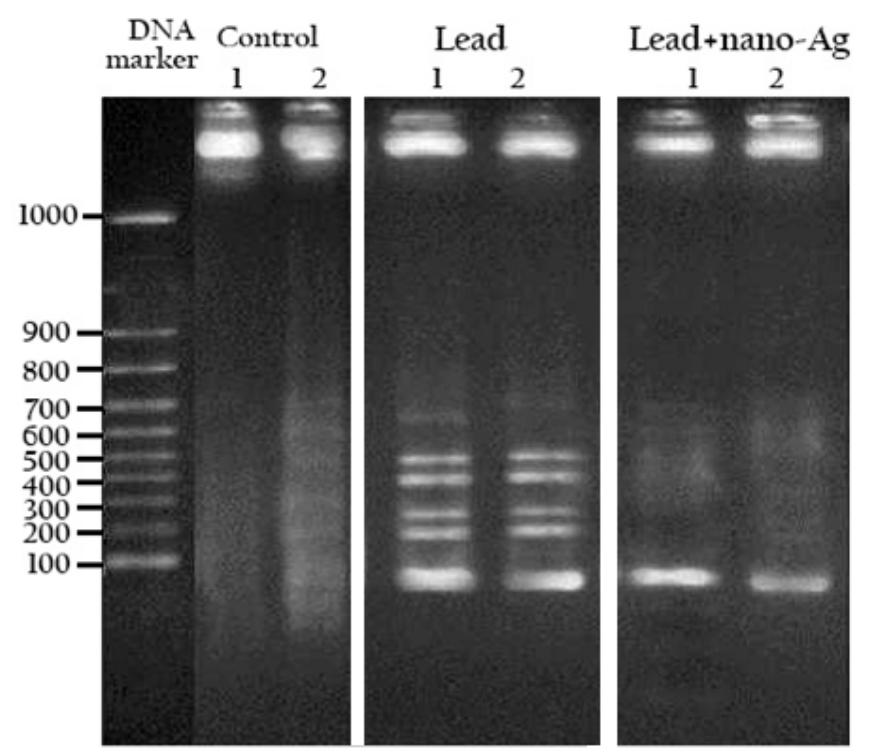

Figure 4. DNA electrophoresis of the studied groups. Where DNA fragmentation was analyzed in two samples from each group

Table 1. Effect of $\mathrm{Ag} / \mathrm{HAp}$ on the hepatic molecular markers in different rat groups

\begin{tabular}{|c|c|c|c|}
\hline & $\begin{array}{c}\text { HSP-70 } \\
(\mathrm{Pg} / \mathrm{g} \text { wt tissue })\end{array}$ & $\begin{array}{c}\text { MMP-9 } \\
(\mathrm{ng} / 100 \mathrm{mg} \text { tissue })\end{array}$ & $\begin{array}{c}\text { Caspase-3 } \\
(\mathrm{ng} / 100 \mathrm{mg} \text { tissue })\end{array}$ \\
\hline control & $1106.76^{\mathrm{c}} \pm 12.10$ & $1.72^{\mathrm{c}} \pm 0.12$ & $75.31^{\mathrm{b}} \pm 0.82$ \\
\hline Lead & $2969.12^{\mathrm{a}} \pm 20.73$ & $8.84^{\mathrm{a}} \pm 0.11$ & $143.16^{\mathrm{a}} \pm 3.15$ \\
\hline Lead $+\mathrm{nAg}$ & $1595.47^{\mathrm{b}} \pm 13.85$ & $3.04^{\mathrm{b}} \pm 0.21$ & $93.83^{\mathrm{a}} \pm 1.17$ \\
\hline
\end{tabular}

Results are the mean $\pm \mathrm{SE}$ of 7 values, with different superscript are significantly different $(\mathrm{P}<0.05)$

Table 2. Effect of $\mathrm{Ag} / \mathrm{HAp}$ on the hepatic inflammatory factors in different rat groups

\begin{tabular}{|c|c|c|c|}
\hline & $\begin{array}{c}\text { IL-2 } \\
(\text { Pg/g wt tissue })\end{array}$ & $\begin{array}{c}\text { TNF- } \alpha \\
(\text { Pg/g wt tissue })\end{array}$ & $\begin{array}{c}\text { IFN- } \gamma \\
(\text { Pg/g wt tissue })\end{array}$ \\
\hline Control & $193.77^{\mathrm{c}} \pm 5.14$ & $379.11^{\mathrm{c}} \pm 7.15$ & $722.11^{\mathrm{c}} \pm 9.01$ \\
\hline Lead & $384.11^{\mathrm{a}} \pm 5.93$ & $613.91^{\mathrm{a}} \pm 6.51$ & $1371.86^{\mathrm{a}} \pm 14.75$ \\
\hline Lead $+\mathrm{nAg}$ & $243.89^{\mathrm{b}} \pm 8.44$ & $346.44^{\mathrm{b}} \pm 6.72$ & $859.12^{\mathrm{b}} \pm 6.43$ \\
\hline
\end{tabular}

Results are the mean $\pm \mathrm{SE}$ of 7 values, with different superscript are significantly different $(\mathrm{P}<0.05)$

Table 3 depicts the effect of synthetic nAg on intoxicated hepatic tissues. MDA levels was significantly increased in lead nitrate induced rats compared to control group whereas, SOD and GPx were significantly depleted $(\mathrm{P} \leq 0.05)$. Nano-Ag prevented the depletion of SOD and GPx content and significantly reduced MDA activity $(\mathrm{P} \leq 0.05)$.

As shown in Table 4 the results of the present study revealed that lead-intoxication produced significant decrease in hepatic ALT activity with a concomitant sharp increase in $\gamma$-GT activity as compared to the normal control group. Therapy of $\mathrm{nAg}$ exhibit significant restoration in above indices towards normal when compared with intoxicated group $(\mathrm{P} \leq 0.05)$.

\section{Histopathological observations}

As shown in Figure 5, the cell plate from the hepatic tissue of the control group has intact structure and the boundary between cells was clear. Hepatocytes showed normal structure with a prominent nucleus, clear central vein (CV) and well-formed sinusoidal spaces(S). Administration of lead nitrate caused extensive hepatic alterations, focal inflammatory cells aggregation $(\mathrm{m})$ in the degenerated parenchymal hepatocytes (d) (Figure 6), associated with diffuse of kuepfer cells and oedema (o), fibrosis (f) and inflammatory cells infiltration in the portal area as shown in Figure 7. There was also granuloma formation (g) consisting of epithelioid cells and giant cells (arrow) appeared clearly in degenerated hepatic parenchyma (Figure 8 and 9). Therapy with nAg showed recovery and regeneration of some hepatocytes, preserved architecture with mild histopathological alterations represented in dilatation and congestion in the portal and central veins associated with some inflammatory Kupffer cells infiltration in the portal and between the hepatocytes (Figure 10-12).

Table 3. Effect of $\mathrm{Ag} / \mathrm{HAp}$ on oxidant/antioxidant status in hepatic tissues of different groups

\begin{tabular}{|c|c|c|c|}
\hline & $\begin{array}{c}\text { MDA } \\
(\mu \mathrm{M} / \mathrm{g} \text { wt tissue })\end{array}$ & $\begin{array}{c}\text { SOD } \\
(\mathrm{U} / \mathrm{g} \text { wt tissue })\end{array}$ & $\begin{array}{c}\text { GPx } \\
(\mathrm{U} / \mathrm{g} \text { wt tissue })\end{array}$ \\
\hline Control & $4.87^{\mathrm{c}} \pm 0.28$ & $376.98^{\mathrm{a}} \pm 4.10$ & $573.38^{\mathrm{a}} \pm 3.22$ \\
\hline Lead & $12.87^{\mathrm{a}} \pm 0.51$ & $179.84^{\mathrm{c}} \pm 3.15$ & $286.87^{\mathrm{c}} \pm 9.11$ \\
\hline Lead $+\mathrm{nAg}$ & $6.12^{\mathrm{b}} \pm 0.40$ & $284.67^{\mathrm{b}} \pm 4.16$ & $402.68^{\mathrm{b}} \pm 4.23$ \\
\hline
\end{tabular}

Results are the mean \pm SE of 7 values, with different superscript are significantly different $(\mathrm{P}<0.05)$

Table 4. Effect of Ag/HAp on hepatic enzymes in different rat groups

\begin{tabular}{|c|c|c|}
\hline & $\begin{array}{c}\text { ALT } \\
\text { (U/g wt tissue) }\end{array}$ & $\begin{array}{c}\gamma \text { - GT } \\
\text { (U/g wt tissue) }\end{array}$ \\
\hline Control & $26.18^{\mathrm{a}} \pm 0.70$ & $7.66^{\mathrm{c}} \pm 0.11$ \\
\hline Lead nitrate & $17.13^{\mathrm{b}} \pm 0.26$ & $22.23^{\mathrm{a}} \pm 1.24$ \\
\hline Lead+ nano-Ag & $24.33^{\mathrm{a}} \pm 0.43$ & $13.11^{\mathrm{b}} \pm 0.65$ \\
\hline
\end{tabular}

Results are the mean \pm SE of 7 values, with different superscript are significantly different $(\mathrm{P}<0.05)$

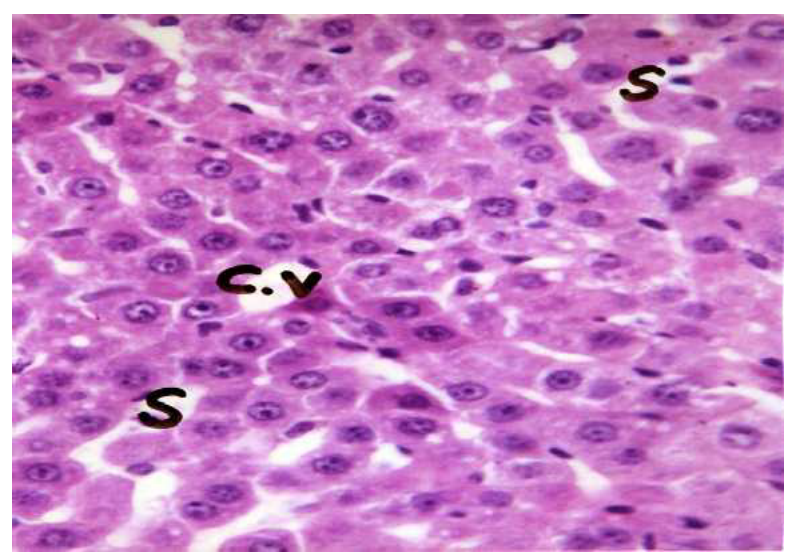

Figure 5. Photomicrograph of liver section of normal rat showing cords of hepatocytes radiating from central vein $(\mathrm{C} . \mathrm{V})$ and separated by blood sinusoids $(\mathrm{S})(\mathrm{H} \& \mathrm{E} \times 400)$

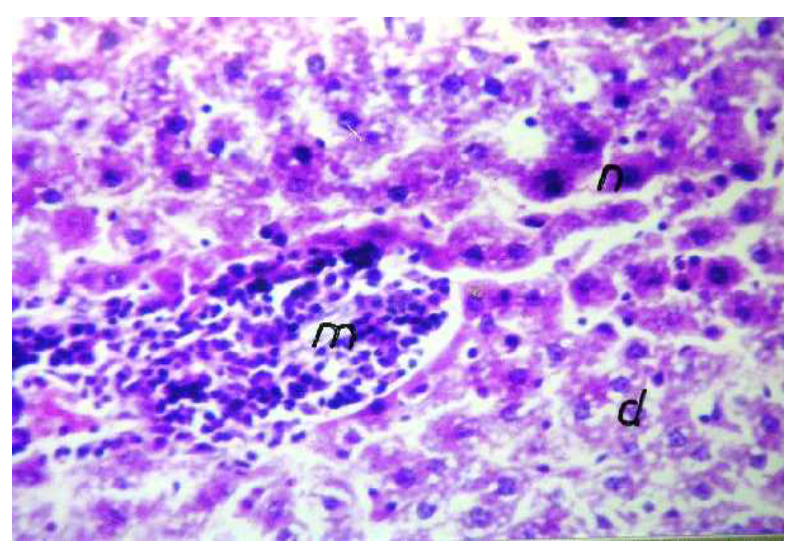

Figure 6. Photomicrograph of liver section of lead-intoxicated rat showing focal inflammatory cells aggregation $(\mathrm{m})$ in degenerated hepatic parenchyma $(\mathrm{d})(\mathrm{H} \& \mathrm{E} \times 400)$ 


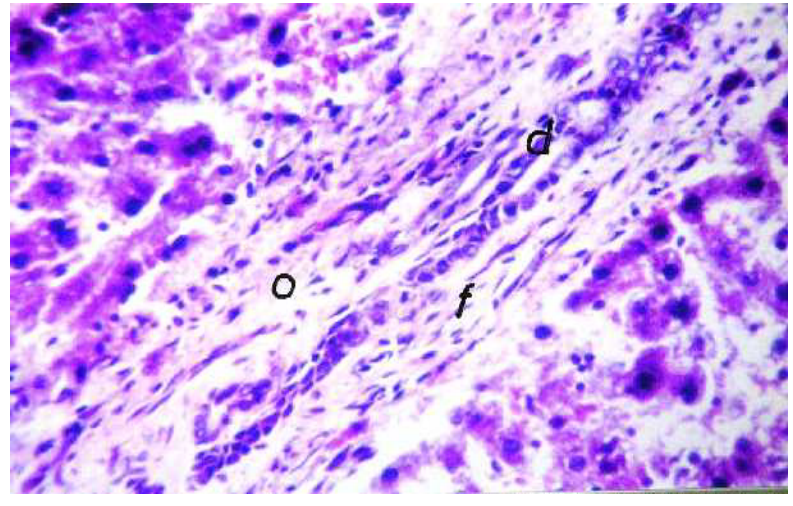

Figure 7. Photomicrograph of liver section of lead-intoxicated rat showing oedema (o) and fibrosis (f) and inflammatory cell infiltration in portal area $(\mathrm{H} \& \mathrm{E} \times 400)$

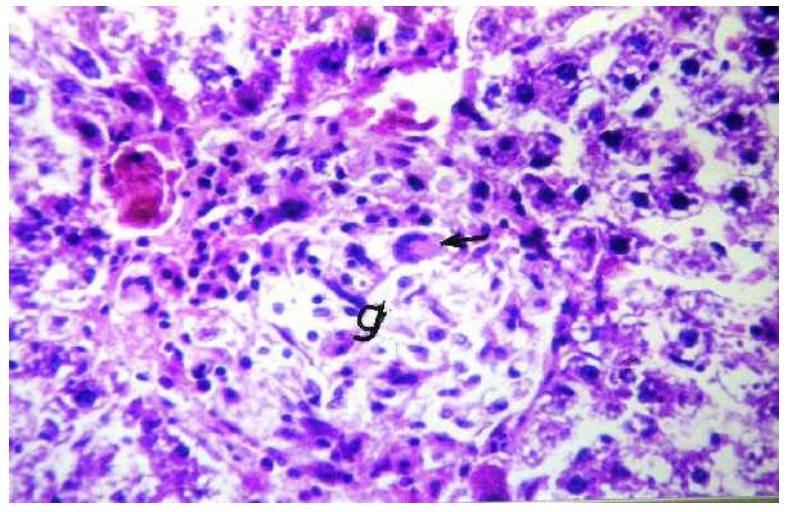

Figure 8. Photomicrograph of liver section of lead-intoxicated rat showing granuloma formation $(\mathrm{g})$ of epitheloid cells and gaint cell (arrow) in degenerated

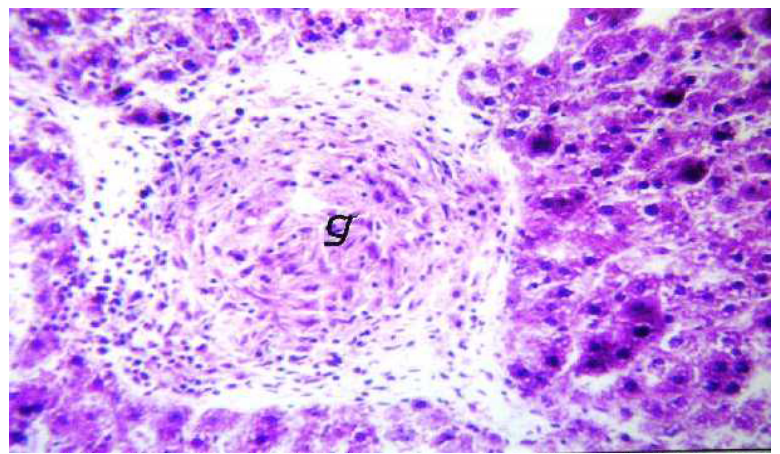

Figure 9. Photomicrograph of liver section of lead-intoxicated rat showing granuloma formation $(\mathrm{g})$ of epitheloid cells without gaint cells $(\mathrm{H} \& \mathrm{E} \times 400)$

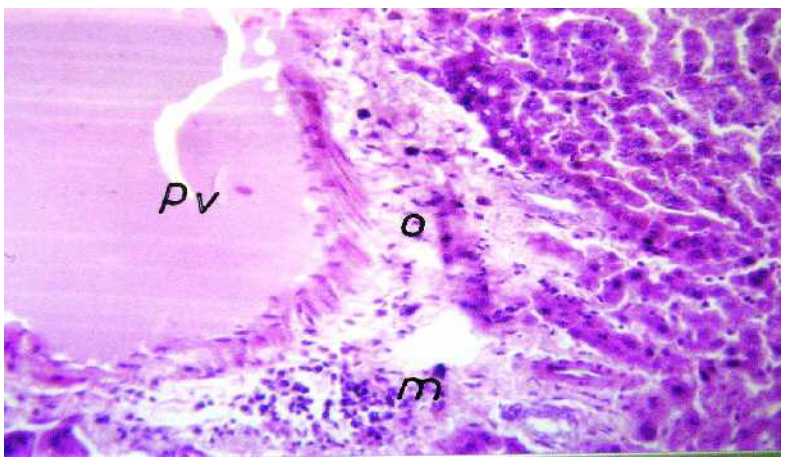

Figure 10. Photomicrograph of liver section of leadintoxicationshowing dilatation in portal vein (pv) withdiffuse of Kuepfer cells and oedema (o) and inflammatory cells infiltration $(\mathrm{m})$ in portal area $(\mathrm{H} \& \mathrm{E} \times 400)$

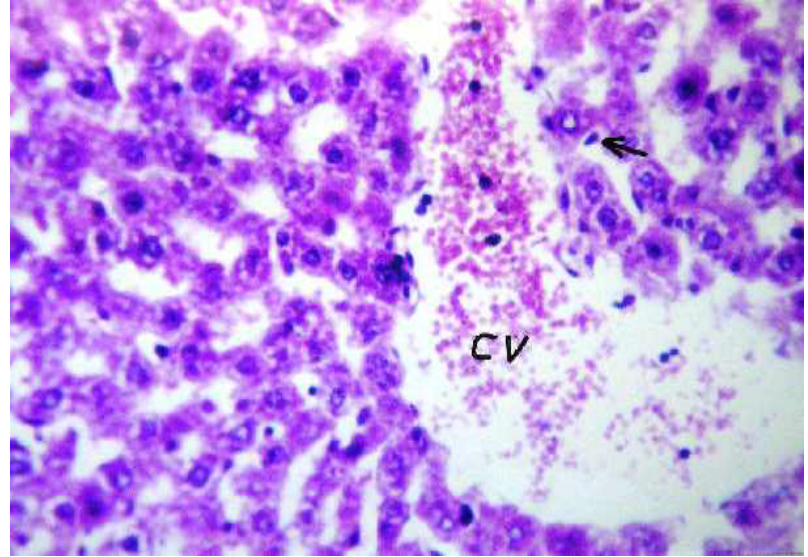

Figure 11. Photomicrograph of liver section of $\mathrm{nAg}$ treated rat after lead intoxication showing dilated central vein (cv) with diffuse few kupffer cells proliferation (arrow) in between the hepatocytes $(\mathrm{H} \& \mathrm{E} \times 640)$

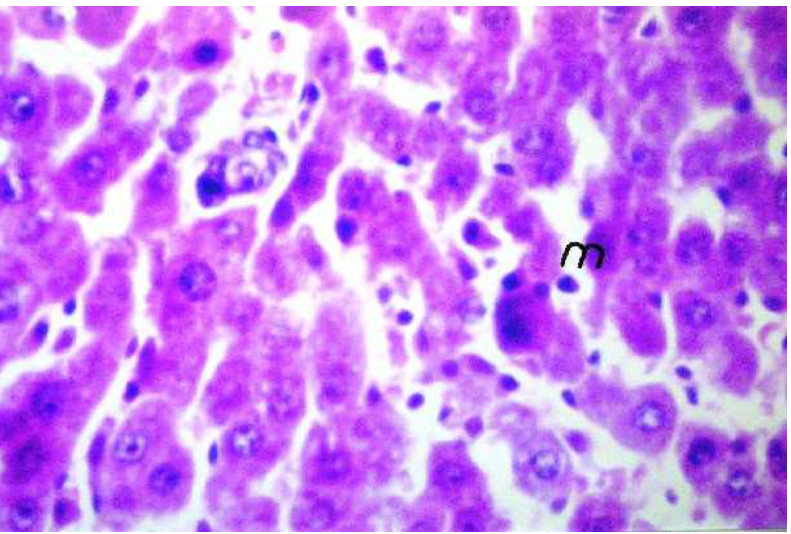

Figure 12. Photomicrograph of liver section of nano-Ag treated rat after lead intoxication showing inflammatory cells infiltration $(m)$ in between the hepatocytes $(\mathrm{H} \& \mathrm{E} \times 640)$

\section{Discussion}

Silver nanoparticles developed through nanotechnology exhibits remarkably unusual physicochemical properties and biological activities. Controversy remains about the beneficial and harmful effects of $\mathrm{nAg}$. These conflicting results may be attributable to variation in particle diameter, structure modification, route and dose of administration. In this study, nAg was synthesized chelated by nHAp to block the release of $\mathrm{Ag}$ ions, the main factor responsible for toxicity, and investigated the biosafety usage as therapeutic drug in overcome the symptoms associated with lead induced hepatotoxicity. The trapping of silver ions may be due to the effect of the gel on the homogeneity with silver ions. The preparation of nHAp performed in situ and selected as raw material for the matrix of the composite because their chemical composition is similar to the mineral phase of hard tissues. The chelation of nHAp to $\mathrm{nAg}$ controlled the releasing of $\mathrm{Ag}^{++}$in intracellular environment. The resultant Ag/HAp nanocomposite allows a better therapeutic strategy without health problems such as releasing of $\mathrm{Ag}^{++}$and /or aggregation of Ag nanoparticles. In the present study, the gel interacts by sorption mechanism. The silver ions didn't slow the attainment of equilibrium or reduce the nHAp crystal stricter. Also, nano size of the used gel enhance the silver ions capture capacity besides the presence of PVAL which works as steric entrapment leading to complete capture of the elements in the solution. A large body of litterateurs investigated the biological role of $\mathrm{nAg}$ with different fabrication methods and versatile analysis but the researchers conducted on this newly synthesis of $\mathrm{nAg} / \mathrm{HAp}$ and its 
efficiency to overcome the deleterious effect of lead nitrate on liver were absent. Moreover, very few studies conducted on intravenous injection of nanoparticles. Thus, the obtained results are often hard to compare with others.

Several studies reported that lead induced oxidative stress is considered the most responsible for the physiological disturbance and organs dysfunction in the body. Such findings were evidenced in the present study, whereas performance of lead toxicity was manifested by disturbance in oxidant/antioxidant status associated with destruction of DNA and increase in cytokines activities as well as alteration in liver function. The induction of oxidative stress and lipid peroxidation with concomitant inhibition of several antioxidant enzymes induced by lead exposure is responsible for possible mechanisms of its toxic effects and major contributors to lead-exposure related diseases [29-31]. Lead reached rabidly to the liver within the first hour after administration and increases the susceptibility of cells to oxidative attack by altering the fatty acid composition leading to generation of ROS and increase in the cytoplasmic membrane permeability to organic substances as well as leakage of hepatic cytosolic enzymes such as ALT into blood [17]. As illustrated by Hsu and Guo [11], lead has high affinity to sulfhydryl (SH) group of reduced glutathione (GSH) leading to inhibition of hepatic antioxidant enzymes and up regulate $\gamma$-GT activity to compensate GSH depletion [32]. As consequence, $\gamma$-GT catalysis the degradation of extracellular GSH through its situation in cell membrane, to favour the recovery of constituent amino acids for intracellular GSH re-synthesis [33]. The expression of $\gamma$-GT is induced by cytokines, including TNF- $\alpha$ [34] and IFN- $\gamma[35]$.

Along with this effect, the production of ROS induces the expression of cytokine mediators associated with DNA damage and ultimately, the apoptosis of hepatocytes [36]. It is worthy mentioned that lead mimics calcium, and then, calcium overload may trigger apoptosis as it can depolarize rod cell mitochondria due to the opening of the permeability transition pore, resulting in the cytochrome release, caspase activation and apoptosis [37]. Thereby, lead effects on DNA directly through dual oxidative mechanisms: 1) Generation of ROS that form DNA lesions by the oxidation of the C-8position of 2 '-deoxyguanosine [12]. 2) Induction of lipid peroxidation produces hydroxyl radical which binds to the double-bond structure of DNA and/or abstracts the hydrogen atoms from it, thus, inducing single and double strand breaks, modification in purine and pyrimidine bases, and deoxyribose sugars [38]. Lead can also affect DNA indirectly through the activation of caspases-3 in the process of irreversible apoptosis [39]. Activated caspase- 3 cleaves and activates the $45-\mathrm{kD}$ subunit of DNA fragmentation factor which in turn leads to the degradation of DNA into nucleosome fragments, a hallmark of apoptosis. In addition, lead interferes with DNA repair mechanisms that normally take place to preserve DNA integrity, thereby increasing DNA fragmentation further [40].

On the other hand, the elevation in hepatic contents of IL-2, IFN- $\gamma$ and TNF- $\alpha$ associated with increase in HSP-70, MMP-9 and caspase- 3 consequence lead-intoxication were a rationale results because the immune system is a dynamic network of cells, tissues, and organs that work coordinated to defend the body against attacks by invaders [41]. However, the oxidative stress activates Tlymphocytes to produce IL-2 as antinflammatory response. IFN- $\gamma$ act to regulate hepatocyte apoptosis, stimulate the macrophage activation and profusion of cytokines [42]. TNF- $\alpha$ is considered a common denominator inactivating both MMP9 expression and cell death via its receptor [43]. The increased MMP-9 concentration is tightly associated with initiation of fibrogenesis by the non-parenchymal hepatic cells [44]. Moreover, the devastating action of ROS extends also into protein to become unfolded protein and accumulated in the endoplasmic reticulum- stress, produced molecular resident-chaperons for adaptation resulted in elevation of hepatic HSP70 level. Since, HSP-70 plays a crucial role following a cellular stress, by selecting and directing aberrant proteins to lysosomes for degradation and preclude the pathway of mitochondrial apoptosis by binding with apoptosis protease activating factor- 1 which in turn recruits procaspase- 9 and pro-caspase- 3 into the apoptosome [45].

The obtained results demonstrated that newly structure of $\mathrm{nAg}$ in $50 \mathrm{mg} / \mathrm{kg}$ b. wt. (cumulative dose, $200 \mathrm{mg} / \mathrm{kg}$ b.wt.) had a significant inhibitory effect on hepatotoxicity pathway of lead nitrate. These findings were manifested by decrease in the oxidative stress, as shown by increased GPx and SOD activity and decrease MDA level with concomitant repair the fragmented DNA bya value exceeded $15 \%$, decreased susceptibility to apoptotic cell death and inflammatory cytokines production with subsequent improvement in liver function. These findings are in line with the studies of [46-49]. The prevailing view is that nAg has a relatively cytotoxic effect because they are not thermodynamically stable and oxidizing intracellular environment of endosomes leads to dissolution of $\mathrm{nAg}$ and releasing of $\mathrm{Ag}^{+}$ions [48]. $\mathrm{Ag}^{+}$ions interact with cell membranes, leading to lower membrane integrity and increased permeability; they are able to bind thiol groups in proteins, causing improper protein function; and they bind to DNA and damage it, resulting in cell apoptosis [9]. Thus, the nano-nanoAgHap composite is not thermodynamically favor and may represent $\mathrm{Ag}^{+}$sequestering and detoxifying mechanism. Such a mechanism would explain the reduction of the potential risks of lead-induced inhibition in antioxidant enzymes, cell death and DNA destruction achieved in the current study. On the other hand, the reversal of increased hepatic enzymes by nAg may be due to membrane stabilizing activity and the prevention of the leakage of intracellular enzymes which indicated the improved the physiological functioning of hepatic tissues [49]. Although numerous studies linked the toxicity of nano-particlesmediated ROS process with inflammatory cytokines production, $\mathrm{nAg}$ has been proven as especially effective at inhibiting inflammations [48,50-53]. The productions of these chemical mediators are key events in the initiation and regulation of an immune response and reducing or blocking these productions and the deleterious effects of cytokines are important aspects of modifying inflammatory processes [48]. In accord, $\mathrm{nAg}$ injection showed a significant inhibitory effect onIL-2, TNF- $\alpha$ and IFN- $\gamma$ as well as HSp-70 and MMp-9 production in leadintoxicated rats indicated that $\mathrm{nAg}$ act by decreasing inflammation through cytokines modulation. As reported elsewhere, nAg has a strong effect on the production of Th1 and Th 2 cytokines oriented immune responses which defined by their ability to secrete the inflammatory cytokines IL-2, TNF- $\alpha$ TNF- $\alpha$ and INF- $\gamma[48,50]$. In addition to the property of $\mathrm{nAg}$ in suppression the inflammatory cytokines expression and NF- $\mathrm{kB}$ activation $[15,54]$.

The various morphologic appearances of the hepatic injury can be difficult to distinguish individually. Therefore, it is very important to correlate biochemical results with the pathologic findings. Liver section of lead-intoxicated rats showed extensive hepatic alterations such as focal inflammatory cells aggregation in the degenerated parenchymal hepatocytes, associated with diffuse of Kuepfer cells and oedema. Fibrosis and inflammatory cells infiltration in the portal area. There was also granuloma formation in degenerated hepatic parenchyma. Hepatic toxicity displays itself in the form of cell vacuolation which is a cellular defense mechanism against injurious substances. These 
substances were segregated in vacuoles and thus prevented from interfering with cellular metabolism. Cytoplasmic vacuolation (oedema) resulted from disturbance in fat metabolism and/or oxidative phosphorylation in the mitochondria with failure of the ATP dependent sodium pump at the cell membrane. As a result, sodium accumulated intracellularly and consequent entry of water into the different cellular compartments ultimately led to cellular swelling [36]. On the other hand, liver fibrosis was the result from ROS pathway mediated by fibrogenic gene expression activation [55]. The activation of Kupffer cells is an important source for induced inflammatory mediators such as TNF- $\alpha$ and IL-2 which in turn contribute to generation of free radicals in the liver [56].

\section{Conclusion}

The outcome of the present study illustrated newly synthesis and characterization for $\mathrm{nAg}$ chelated by nHAp. Such fabrication provides a biosafe composite with unique chemical and biological properties possess anti-hepatotoxicity effect. This implies the future development of new or adapted methods appropriate to assess new medicinal products involving silver nanoparticles. Although future studies should require to be conducted to explore the importance of this chemical composition of $\mathrm{nAg}$ on cellular and molecular responses in various tissues, the available data suggest that silver nanoparticles can be engineered to become part of the next generation of biocompatible drug.

\section{Author contributions}

Eman I. Abdel-Gawad, Emad M. Elsherbiny and Sameh A. Awwad analysed the data, drafted the manuscript, designed the study, provided necessary support, and directed implementation and data collection.

\section{References}

1. Sahu SC, Zheng J, Graham L, Chen L, Ihrie J (2014) Comparative cytotoxicity of nanosilver in human liver HepG2 and colon Caco2 cells in culture. $J$ Appl Toxicol 34: 1155-1166.

2. Faedmaleki F, Shirazi F, Salarian AA (2014) Toxicity effect of silver nanoparticles on mice liver primary cell culture and HepG2 cell line. Iran J Pharm Res 13: 235-242.

3. Braun GB (2014) Etchable plasmonic nano particle probes to image and quantify cellular internalization. Nat Mater 13: 904-911.

4. Goodman AM (2014) The surprising in vivo instability of near-IR-absorbing hollow Au-Ag nanoshells. ACS Nano 8: 3222-3231. [Crossref]

5. Chen D, Xi T, Bai J (2007) Biological effects induced by nano silver particles: in vivo study. Biomed Mater 2 (3): 126-130.

6. Nazir S (2011) Novel and cost-effective green synthesis of silver nano particles and their in vivo antitumor properties against human cancer cell lines. J Biosci Tech 2: 425-430.

7. Park J (2011) Size dependent macrophage responses and toxicological effects of $\mathrm{Ag}$ nano particles. Chem Commun 47: 4382-4384.

8. De Jong WH (2013) Systemic and immunotoxicity of silver nano particles in an intravenous 28 days repeated dose toxicity study in rats. Biomaterials 34: 8333-8343

9. Silva T (2014) Particle size, surface charge and concentration dependent ecotoxicity of three organo-coated silver nanoparticles: Comparison between general linear modelpredicted and observed toxicity. Sci Total Environ 968-976.

10. Wijnhoven SWP (2009) Nano-silver: A review of available data and knowledge gaps in human and environmental risk assessment. Nano-toxicology 3: 109-138.

11. Hsu PC, Guo YL (2002) Antioxidant nutrients and lead toxicity. Toxicology 180: 33-44.

12. Chen H (2010) Magnetic bead-based approach to monitoring of cigarette smoke induced DNA oxidation damage and screening of natural protective compounds. Talanta 80:1216-1221.
13. Shayesteh TH (2014) Effects of silver nano particle (Ag NP)on oxidative stress, liver function in rat: hepatotoxic or hepatoprotective? Biological Sciences and Pharmaceutical Research 2: 40-44.

14. ATSDR (1999) Toxicological profile for lead, Washington DC, US department of health and human services, public health service, Agency for toxic substances and disease registry

15. Shin S (2012) The effect of nano-silver on allergic rhinitis model in mice. Clinical and Experimental Otorhinolaryngology 5: 222-227.

16. Hasan SM (2011) Effect of lead toxicity on liver of male albino mice ultrastructural study. Kufa Med Journal 14: 214.

17. Bechara EJH (2004) Lead poisoning and oxidative stress. Free Radic Biol Med 36: 22

18. Mudipalli A (2007) Lead hepatotoxicity \& potential health effects. Indian J Med Res 126: 518-527. [Crossref]

19. Diaz M (2009) Synthesis and antimicrobial activity of a silver-hydroxy apatite nano composite. Journal of Nanomaterials 6.

20. Abdel Fattah WI (2006) Nano Hydroxy apatite for environmental applications. Isotope and radiation research $38: 429-436$.

21. Bortner CD (1995) The role of DNA fragmentation in apoptosis. Trends Cell Biol 5 : 21-25.

22. Teppo AM and Maury CPJ (1987) Radioimmunoassay of tumor necrosis factor in serum. Clinical Chemistry 33

23. Staehelin T, Stahli C, Hobbs DS, Peskta S (1981) A rapid quantitative assay of high sensitivity for human leukocyte interferon with monoclonal antibodies. Meth Enzym 79: 589-595.

24. Janknegt PJ (2007) A comparison of quantitative and qualitative superoxide dismutase assays for application to low temperature microalgae. J Photochem Photobiol 87: 218 226

25. Paglia DE, Valentine WN (1967) Studies on the quantitative and qualitative characterization of erythrocyte glutathione peroxidise. J Lab Clin Med 70: 158-169.

26. Erdelmeier I, Gerard-Mounnier, D, Yadan J, Chaudiere D (1998) Reactions of $\mathrm{N}$-methyl-2-phenylindole with malondialdehyde and 4-hydroxyalkenals. Mechanistic aspects of the colorimetric assay of lipid peroxidation. Chem Res Toxicol 11: 11841194.

27. Reitman S, Frankel S (1957) A colorimetric method for the determination of serum glutamic oxalacetic and glutamic pyruvic transaminases. Am J Clin Pathol 28: 56-63.

28. Young DS (1995) Effects of drugs on clinical laboratory tests, 4th ed. AACC Press.

29. Bolin CM, Basha R, Cox D, Zawia NH, Maloney B (2006) Exposure to lead and exposed to lead using micronucleus assay, comet assay and TCR gene mutation test. Toxicology 223: 219-226.

30. Patrick L (2006) Lead toxicity part II: The role of free radical damage and the use of antioxidants in the pathology and treatment of lead toxicity. Altern Med Rev 11: 114127.

31. Arif M, Kabir F, Hassan F, Zaved Waise TM, Ehsanul MD (2008) Increased DNA damage in blood cells of rat treated with lead as assessed by comet assay. Bangladesh J Pharmacol 3: 97-101.

32. Offor SJ, Mbagwu HOC, Orisakwe OE (2017) Lead induced hepato-renal damage in male albino rats and effects of activated charcoal. Front Pharmacol 8: 107.

33. Liu JG (2012) Effect of two selenium sources on hepatocarcinogenesis and several angiogenic cytokines indiethyl nitrosamine-induced hepatocarcinoma rats. $J$ Trace Elem Med Biol 26: 255-261.

34. Daubeuf S, Duvoix A, Wellman-Rousseau M, Diederich M, Visvikis A (2004) Phorbol ester regulation of the human gammaglutamyl transferase gene promoter. Biochem Biophys Res Commun 313: 300-307.

35. Bouman L, Sanceau J, Rouillard D, Bauvois B (2002) Gammaglutamyl transpeptidase expression in Ewing's sarcoma cells: up-regulation by interferons. Biochem J 364: 719 724.

36. Metwally EAM, Negm FA, Shams El-din RA, Nabil EM (2015) Anatomical and histological study of the effect of lead on hepatocytes of albino rats. International Journal of Biomedical Materials Research 3: 34-45.

37. He L, Poblenz AT, Medrano CJ, Fox DA (2000) Lead and calcium produce rod photoreceptor cell apoptosis by opening the mitochondrial permeability transition pore. J Biol Chem 275: 12175-84. [Crossref] 
38. Cooke MS, Evans MD, Dizdaroglu M, Lunec J (2003) Oxidative DNA damage: mechanisms, mutation, and disease. Faseb J 17: 1195-214.

39. Gargioni RF, Filipak Neto F, Buchi DF (2006) Cell death and DNA damage in peritoneal macrophages of mice (Mus musculus) exposed to inorganic lead. Cell Biology International 30: 615-623

40. Haouas Z, Sallem A, Zidi I (2014) Hepatotoxic effect of lead acetate in rats: Histopathological and Cytotoxic Studies. J Cytol Histol 5: 1-6.

41. Christensen JE, Thomsen AR (2009) Co-ordinating innate and adaptive immunity to viral infection: mobility is the key. APMIS 117: 338-355

42. Wullaert A, van Loo G, Heyninck K, Beyaert R (2007) Hepatic tumor necrosis factor signalling and nuclear factor-kappa B: effects on liver homeostasis and beyond. Endocrine Reviews 28: 365-86.

43. Giannelli G, Bergamini C, Marinosci F, Fransvea E, Napoli N, et al. (2006) Antifibrogenic effect of IFN-alpha2b on hepatic stellate cell activation by human hepatocytes. J Interferon Cytokine Res 26: 301-308

44. Knittel T, Kobold D, Saile B, Grundmann A, Neubauer K, et al. (1999) Rat liver myofibroblasts and hepatic stellate cells: different cell populations of the fibroblast lineage with fibrogenic potential. Gastroenterology 117: 1205-1221.

45. Mayer MP, Bukau B (2005) Hsp70 chaperones: Cellular functions and molecular mechanism. Cellular and Molecular Life Sciences 62: 670.

46. Al-Rejaie SS, Aleisa AM, Al-Yahya AA, Bakheet SA, Alskeikh A, et al. (2009) Progression of diethyl nitrosamine-induced hepatic carcinogenesis in carnitinedepleted rats. World J Gastroenterol 15: 1373-1380.

47. Hosseini E (2013) Study on physiological and biochemical activity of silver nano particles in male and female mice bull. Env Pharmacol Life Sci 2: 21-26.
48. Gonzalez-Carter DA, Leo BF, Ruenraroengsak P, Chen S, Goode AE, et al. (2017) Silver nano particles reduce brain inflammation and related neurotoxicity through induction of H2S-synthesizing enzymes. Scientific Reports 7: 42871. [Crossref]

49. Singh A, Darb MY, Joshic B, Sharmac B, Shrivastavaa S, et al. (2018) Phytofabrication of silver nanoparticles: Novel Drug to overcome hepatocellular ailments. Toxicology Reports 5: 333-342.

50. Shin S, Ye MK, Hae-Sic KB, Kang HS (2007) The effects of nano-silver on the proliferation and cytokine expression by peripheral blood mononuclear cells. International Immuno pharmacology 7: 1813-1818

51. Castillo PM, Herrera JL, Fernandez-Montesinos R, Caro C, Zaderenko AP, et al. (2008) Tiopronin monolayer-protected silver nano particles modulateIL-6 secretion mediated by Toll-like receptor ligands. Nanomed 3: 627-635.

52. Klippstein R, Montesinos RF, Castillo PM, Zaderenko AP, Pozo D (2010) Silver nano particles interactions with the immune system: implications for health and disease. silver nano particles. David Pozo Perez (Ed.), ISBN: 978-953-307-028-5.

53. Melo PS, Marcato PD (2011) Nano particles in treatment of thermal injured rats: Is it safe? Journal of Physics: Conference Series 304: 012027.

54. Bhol KC, Schechter PJ (2005) Topical nano crystalline silver cream suppresses inflammatory cytokines and induces apoptosis of inflammatory cells in a murine model of allergic contact dermatitis. Br J Dermatol 152: 1235-1242.

55. Bartosz G (2008) Reactive oxygen species: destroyers or messengers. Biochemical Pharmacology 77: 1303-1315. [Crossref]

56. Ahamed M and Siddiqui MKJ (2007) Low level lead exposure and oxidative stress current opinions. Clinica Chimica Acta 383: 57-64.

Copyright: $\mathbb{C} 2021$ Abdel-Gawad EI. This is an open-access article distributed under the terms of the Creative Commons Attribution License, which permits unrestricted use, distribution, and reproduction in any medium, provided the original author and source are credited. 